\title{
Variability and problem of species identification of sculpins of the genus Cyphocottus (Pisces: Cottidae)
}

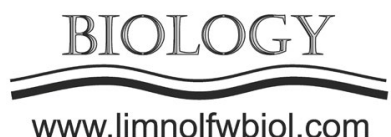

Bogdanov B.E.

Limnological Institute, Siberian Branch of the Russian Academy of Sciences, Ulan-Batorskaya Str., 3, Irkutsk, 664033, Russia

ABSTRACT. Based on the material collected during the fieldwork seasons from 1996 to 2007 in the amount of 223 specimens, we studied phenetic relationships and taxonomic structure of the genus Cyphocottus. Two valid species, C. megalops and C. eurystomus, within the taxonomic boundaries established by D.N. Taliev (1955) were confirmed in the genus Cyphocottus. Interspecific differences in C. eurystomus are manifested in greater values of interorbital distance, the height of the head, body and caudal peduncle, as well as in smaller values of eye diameter and caudal peduncle length. Polymorphism in the definitive sizes, colour and the number of neuromasts in the lateral line is typical of $C$. eurystomus. At the same time, all populations have specific characters of $C$. eurystomus different from C. megalops. We found no intraspecific variability in C. megalops.

Keywords: Baikal endemic sculpins, genus Cyphocottus, phenetic and taxonomic relationships, Lake Baikal

\section{Introduction}

V.G. Sideleva founded the genus Cyphocottus, humpback sculpins, including two species, C. megalops and C. eurystomus (Sideleva, 2003). The name of the genus Cyphocottus originates from the Latinized Greek words "cyphos", which means humpback, and "cottus", which is sculpin, thus, reflecting the morphological feature of these fish. Genetic studies confirmed the validity of this genus (Kontula et al., 2003). Type species, C. megalops, was originally described within the genus Cottus (Gratzianov, 1902). Later, it was placed within the genera Limnocottus (Berg, 1906; Sideleva, 1982), Abyssocottus (Gratzianov, 1907) and Asprocottus (Taliev, 1955). Overall, during the studies, four species were described: Cottus megalops (Gratzianov, 1902); Limnocottus megalops elegans (Taliev, 1948) and Asprocottus megalops eurystomus, which included two subspecies, namely the "type" subspecies inhabiting the Selenga shallow water, Barguzin Bay and the Maloye More Strait and the "Southern Baikal" subspecies inhabiting, as follows from its name, the southern basin of Lake Baikal. The latter subspecies differs from the former one by a variegated colour and some plastic and meristic characters (Taliev, 1955). Subsequently, the name $C$. eurystomus was entrenched not only for this subspecies but also for all spotty individuals as well as the name C. megalops - for monochromic individuals (Sideleva, 2003).

The confusion in the identification of taxa is due to two circumstances. First, the original description of C. megalops was made for an juvenile individual with exterior features that were not completely formed. Second, for a long time, there were no new findings of this species. Between the first finding in 1891, "the second discovery" of the species in 1943 and our samplings from 2000 to 2007, the intervals were more than half a century. The collected material allows us to solve the problems concerning the identification of taxa and consider their intraspecific variability.

\section{Material and methods}

Thisstudy was based on thematerial collected from 1996 to 2007. A total of 223 specimens were examined (Table 1). The species were identified by characters indicated by D.N. Taliev (1955) and V.G. Sideleva

*Corresponding author.

E-mail address: bakhtiar.bogdanov@mail.ru (B.E. Bogdanov) 
Table 1. List of samples and analyses

\begin{tabular}{|c|c|c|c|c|}
\hline $\begin{array}{l}\text { No. of } \\
\text { samples }\end{array}$ & Name of locality & Date & $\begin{array}{l}\text { Number of } \\
\text { neuromasts }\end{array}$ & $\begin{array}{l}\text { Other morphologi- } \\
\text { cal characters }\end{array}$ \\
\hline \multicolumn{5}{|c|}{ Cyphocottus megalops } \\
\hline 1 & Chivyrkuy Bay estuary & 16 August 2006 & 1 & 1 \\
\hline 2 & Barguzin Bay & 19 June 2000 & 4 & 5 \\
\hline \multirow[t]{2}{*}{3} & the Selenga shallow water & 27 May 2007 & 7 & 7 \\
\hline & the Selenga shallow water & 17 June 2000 & - & 9 \\
\hline 4 & area near the estuary of the Buguldeika River & 08 June 2003 & 10 & 18 \\
\hline \multicolumn{5}{|c|}{ Cyphocottus eurystomus (monochromic form) } \\
\hline 5 & area near the estuary of the Kichera River & 02 June 2007 & 5 & 5 \\
\hline 6 & Frolikha Bay & 04 June 2002 & - & 9 \\
\hline 7 & Tompa Bay & 05 June 2002 & - & 14 \\
\hline 8 & Shegnanda Cape & 06 June 2002 & 5 & 5 \\
\hline \multirow[t]{2}{*}{9} & Bolshiye Vorota Strait & November 2004 & 25 & 25 \\
\hline & Bolshiye Vorota Strait & 30 May 2007 & 6 & 6 \\
\hline 10 & Khoboy Cape & 19 June 2000 & 3 & 8 \\
\hline 11 & the Selenga shallow water & 29 October 2004 & 30 & 30 \\
\hline \multicolumn{5}{|c|}{ Cyphocottus eurystomus (spotty form) } \\
\hline 12 & Chivyrkuy Bay estuary & $\begin{array}{l}20 \text { September } \\
1999\end{array}$ & 11 & 11 \\
\hline 13 & area near the estuary of the Buguldeika River & 08 June 2003 & 25 & 25 \\
\hline 14 & Gremyachinsk Cape & March 2005 & 10 & 10 \\
\hline \multirow[t]{2}{*}{15} & Bolshaya Kosa Cape & 07 June 2002 & 1 & 1 \\
\hline & Solontsovaya Bay & 22 June 2000 & 1 & 1 \\
\hline \multirow[t]{2}{*}{16} & Ushkany Islands & 21 June 2000 & 1 & 6 \\
\hline & Ushkany Islands & 07 June 2003 & 1 & 1 \\
\hline \multirow[t]{6}{*}{17} & Bolshiye Koty Bay & July 2003 & 1 & 1 \\
\hline & Listvenichny Bay & 13 February 1996 & 5 & 5 \\
\hline & Listvenichny Bay & December 2000 & 3 & 6 \\
\hline & Listvenichny Bay & December 2001 & 3 & 5 \\
\hline & Listvenichny Bay & May 2002 & 7 & 7 \\
\hline & area near the Slyudyanka town & March 2000 & 2 & 2 \\
\hline
\end{tabular}

(2003). Due to discrepancies in the identification of $C$. megalops in the above references, the two forms were compared for compliance with the characters of the holotype descripted by V.I. Gratzianov (1902) for ten plastic characters. As an alternative, the following was used: the $C$. megalops (sensu Sideleva, 2003) selection consisting of 15 juvenile individuals collected in the northern part of Lake Baikal, Frolikha and Tompa bays (form A in Table 2) and the C. megalops (sensu Taliev, 1955) selection consisting of 40 adult individuals from different areas of Lake Baikal (form B in Table 2). The study of interspecific and intraspecific variability was carried out on 17 samples by 17 meristic and 29 plastic characters. The selections were compared by principal component analysis (PCA) technique using the SPSS 8.0 software (Laerd Statistics, 2015)

\section{Results and discussion}

\section{Identification of taxa}

The analysis of phenetic relationships of the juvenile C. megalops (sensu Sideleva, 2003) specimens, the adult $C$. megalops (sensu Taliev, 1955) specimens and the $C$. megalops holotype has revealed that these selections diverge in the space of principal components by such characters as eye diameter, the height of body and head in the space of the first principal component as well as by the postorbital distance and the interorbital distance, head length and caudal peduncle length in the space of the second principal component (Table 2). The $C$. megalops holotype occupied the centre on the scatter plot of the C. megalops (sensu Taliev, 1955) selection (Fig. 1). Therefore, the identification of taxa proposed 
by D.N. Taliev (1955) should be considered correct, to which we will adhere below.

The distinctive features of $C$. megalops are an oblong body, large oval eyes (eye diameter is usually larger than the snout length) and monochromic colour: the brown back, yellow-brown sides and yellowish-grey fins (Fig. 2A). The distinctive features of $C$. eurystomus are a tall fusiform body forming a hump behind the occiput and round eyes with a diameter smaller than the snout length. The colour of the body and fins varies significantly (Fig. 2B-2E); therefore, the division into monochromic and spotty forms is rather nominal.

\section{Variability of definitive sizes}

There were no differences in the sizes of adult C. megalops individuals (Table 3). The total length (TL) of the studied specimens ranged from 93 to $127 \mathrm{~mm}$. D.N. Taliev (1955) gave similar data (110$120 \mathrm{~mm}$ ). In contrast, the sizes of C. eurystomus are subject to significant variability. Four size groups can be distinguished: large (TL up to $215,160-185 \mathrm{~mm}$ on average) individuals inhabiting the Selenga shallow

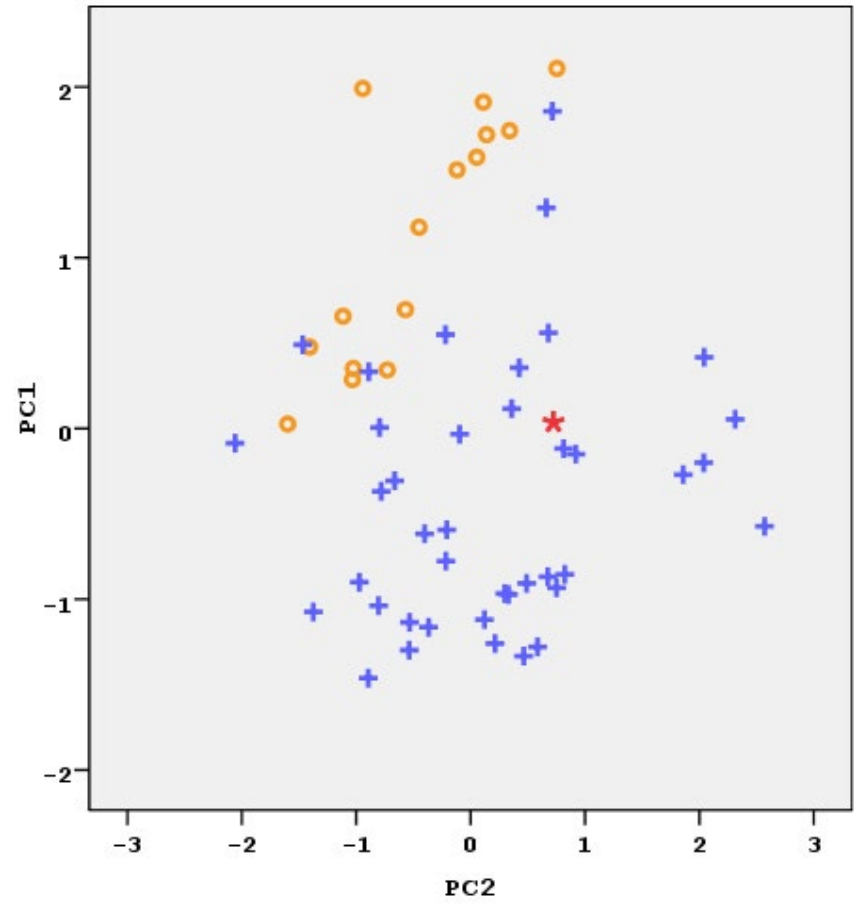

Fig.1. Phenetic relationships between the holotype of C. megalops and potentially conspecific specimens: red star holotype of C. megalops, orange circles - juvenile specimens of C. megalops sensu Sideleva (2003), blue cross - adult specimens of C. megalops sensu Taliev (1955).

Table 2. Values of the key morphological characters and component score coefficient matrix for analysis of the Cyphocottus megalops identification

\begin{tabular}{|c|c|c|c|c|c|}
\hline & \multirow{2}{*}{$\begin{array}{l}\text { Holotype of } C . \\
\text { megalops }\end{array}$} & \multicolumn{2}{|c|}{ Examined forms } & \multicolumn{2}{|c|}{ Principal Component } \\
\hline & & A & B & 1 & 2 \\
\hline Total length (mm) & 71.0 & $63.6-84.2$ & $\frac{110.9}{93.2-127.1}$ & \multicolumn{2}{|c|}{$\%$ of Variance } \\
\hline Standard length (mm) & 60.0 & $52 \frac{60.8}{4-69.3}$ & 76. $\frac{92.4}{0-107.1}$ & 38.340 & 16.777 \\
\hline \multicolumn{6}{|c|}{ Plastic characters in \% of standard length } \\
\hline head length & 31.7 & $\frac{34.3 \pm 0.77}{33.0-35.8}$ & $\frac{31.7 \pm 0.91}{29.6-33.9}$ & 0.188 & -0.218 \\
\hline height of the trunk & 18.3 & $\frac{20.0 \pm 1.43}{17.5-21.9}$ & $\frac{15.7 \pm 2.28}{12.2-21.7}$ & 0.232 & -0.136 \\
\hline height of caudal peduncle & 5.0 & $\frac{5.5 \pm 0.29}{5.1-6.0}$ & $\frac{5.4 \pm 0.35}{4.4-6.3}$ & 0.156 & 0.231 \\
\hline length of caudal peduncle & 19.2 & $\frac{16.9 \pm 1.07}{15.2-19.2}$ & $\frac{16.4 \pm 1.21}{13.7-18.8}$ & -0.003 & -0.373 \\
\hline \multicolumn{6}{|c|}{ Plastic characters in $\%$ of head length } \\
\hline snout length & 28.9 & $\frac{27.9 \pm 1.36}{25.5-31.3}$ & $\frac{26.9 \pm 1.78}{19.7-30.9}$ & 0.094 & 0.155 \\
\hline longitudinal eye diameter & 31.6 & $\frac{24.7 \pm 1.44}{21.9-27.1}$ & $\frac{27.3 \pm 2.12}{21.7-32.4}$ & -0.176 & 0.017 \\
\hline postorbital distance & 44.7 & $\frac{41.1 \pm 1.66}{37.9-44.5}$ & $\frac{41.6 \pm 1.74}{37.5-46.1}$ & 0.041 & 0.438 \\
\hline width of the head & 63.2 & $\frac{70.4 \pm 4.68}{63.2-79.3}$ & $\frac{63.8 \pm 9.73}{53.0-94.7}$ & 0.166 & -0.166 \\
\hline head height near occiput & 50.0 & $\frac{52.8 \pm 2.84}{47.2-56.0}$ & $\frac{46.7 \pm 4.18}{41.0-61.1}$ & 0.235 & -0.050 \\
\hline interorbital distance & 10.5 & $\frac{7.2 \pm 1.50}{5.2-9.6}$ & $\frac{6.2 \pm 1.54}{3.4-11.0}$ & 0.151 & 0.302 \\
\hline
\end{tabular}

Note: Above the line - average values and standard deviations, below the line - limits of variability of the characteristic value. Symbols: form A - juveniles of C. megalops sensu Sideleva, 2003; form B - C. megalops sensu Taliev, 1955. 
water and the northern part of the Maloye More Strait; medium individuals (TL up to $165 \mathrm{~mm}$, 130-145 $\mathrm{mm}$ on average); small individuals (TL up to $135-145 \mathrm{~mm}, 100-125 \mathrm{~mm}$ on average) and dwarfs (TL up to $96 \mathrm{~mm}$ ). Small and medium individuals are found throughout Lake Baikal; dwarfs were found only at one site, near Khoboy Cape at a depth of $100 \mathrm{~m}$.

\section{Variability of morphometric characters}

The study of the variability in the number of neuromasts in sensory lines has revealed the absence of interspecific differences. At the intraspecific level, in C. megalops and monochromic form of $C$. eurystomus, the number of neuromasts in the lateral line increases from the northern to the southern part of the range (Table 3). The greatest number of neuromasts is typical of the C. eurystomus population in the Selenga shallow water. The scatter plot of the selections in the space of principal components (Table 4, Fig. 3A) shows this as a displacement of the scatter area of this population along the axis of the second principal component to the right side of the plot.

Analysis (PCA) of other morphometric characters showed that body height, caudal peduncle height, head height near occiput, and interorbital distance yield the greatest positive loading on the first principal component, and caudal peduncle length and eye diameter the negative one. These characters determine interspecific differences. Body length yields the greatest positive loading on the second principal component, and head length - the negative one. These characters determine the difference of $C$. eurystomus in the Selenga shallow water from other populations of this species (Table 5, Fig. 3B)

\section{Conclusions}

This study has revealed interspecific differences between $C$. megalops and C. eurystomus manifested in greater values of interorbital distance, the height of the head, body and caudal peduncle, as well as smaller values of eye diameter and caudal peduncle length, in C. eurystomus. The population of $C$. eurystomus in the Selenga shallow water differs from other populations of this species by the same characters. Therefore, this population and C. megalops represent the
Table 3. Component score coefficient matrix for analysis of the number of neuromasts in the sensory lines of 17 samples of the Cyphocottus sculpins

\begin{tabular}{|c|c|c|}
\hline \multirow[t]{4}{*}{ Characters } & \multicolumn{2}{|c|}{ Principal Component } \\
\hline & 1 & 2 \\
\hline & \multicolumn{2}{|c|}{$\%$ of Variance } \\
\hline & 37.181 & 15.540 \\
\hline $\begin{array}{l}\text { number of neuromasts in a left supraor- } \\
\text { bital line }\end{array}$ & 0.140 & -0.151 \\
\hline right supraorbital line & 0.150 & -0.176 \\
\hline left infraorbital line & 0.155 & -0.012 \\
\hline right infraorbital line & 0.151 & -0.049 \\
\hline left temporal line & 0.131 & -0.052 \\
\hline right temporal line & 0.140 & -0.106 \\
\hline left occipital line & 0.118 & 0.063 \\
\hline right occipital line & 0.137 & 0.063 \\
\hline left preopercular-mandibular line & 0.157 & -0.107 \\
\hline right preopercular-mandibular line & 0.159 & -0.023 \\
\hline left lateral line & 0.090 & 0.470 \\
\hline right lateral line & 0.085 & 0.474 \\
\hline
\end{tabular}
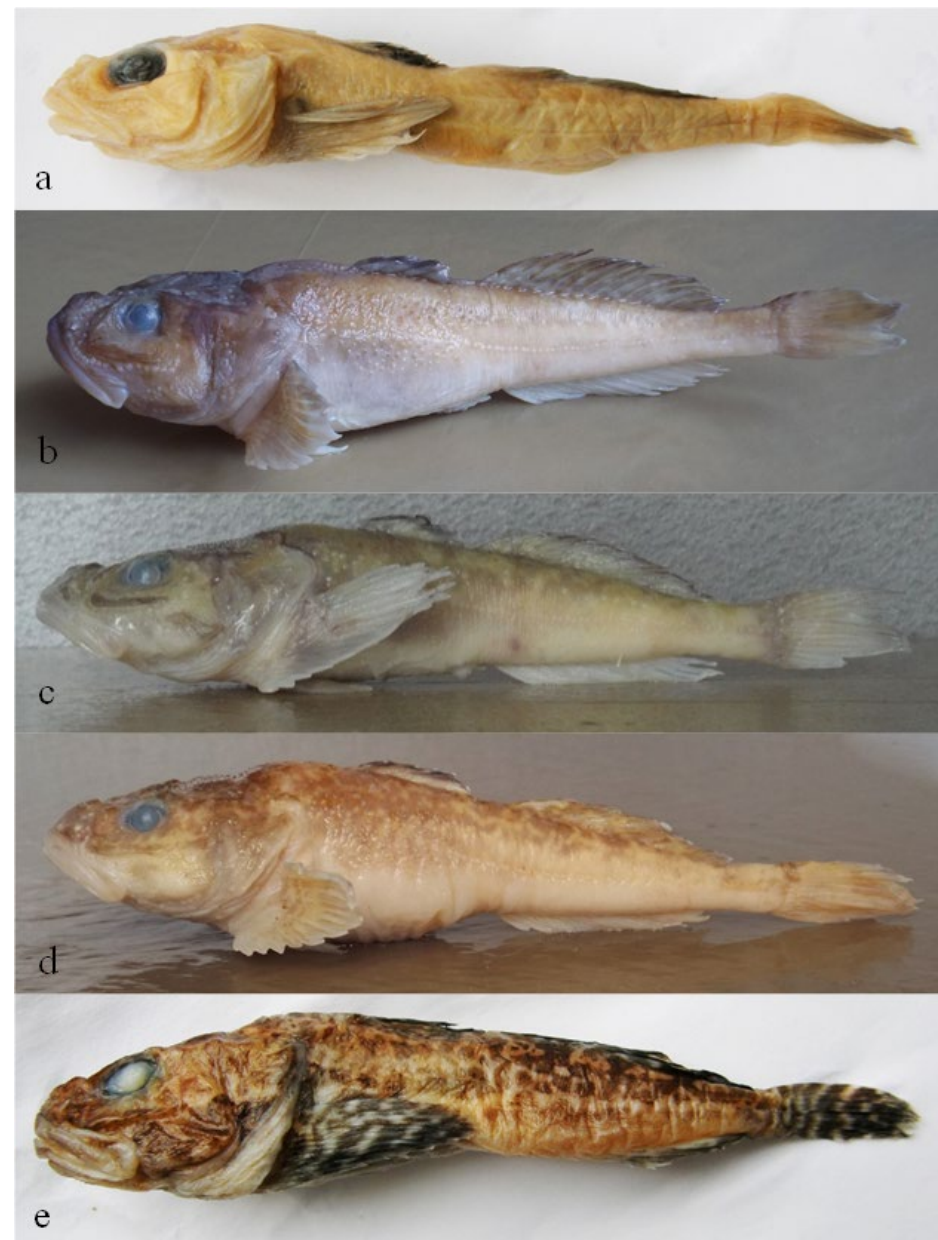

Fig.2. Variability of colours: A. C. megalops; B-E. C. eurystomus: (B and C) - monochromic form; (D and E) - spotty form. 

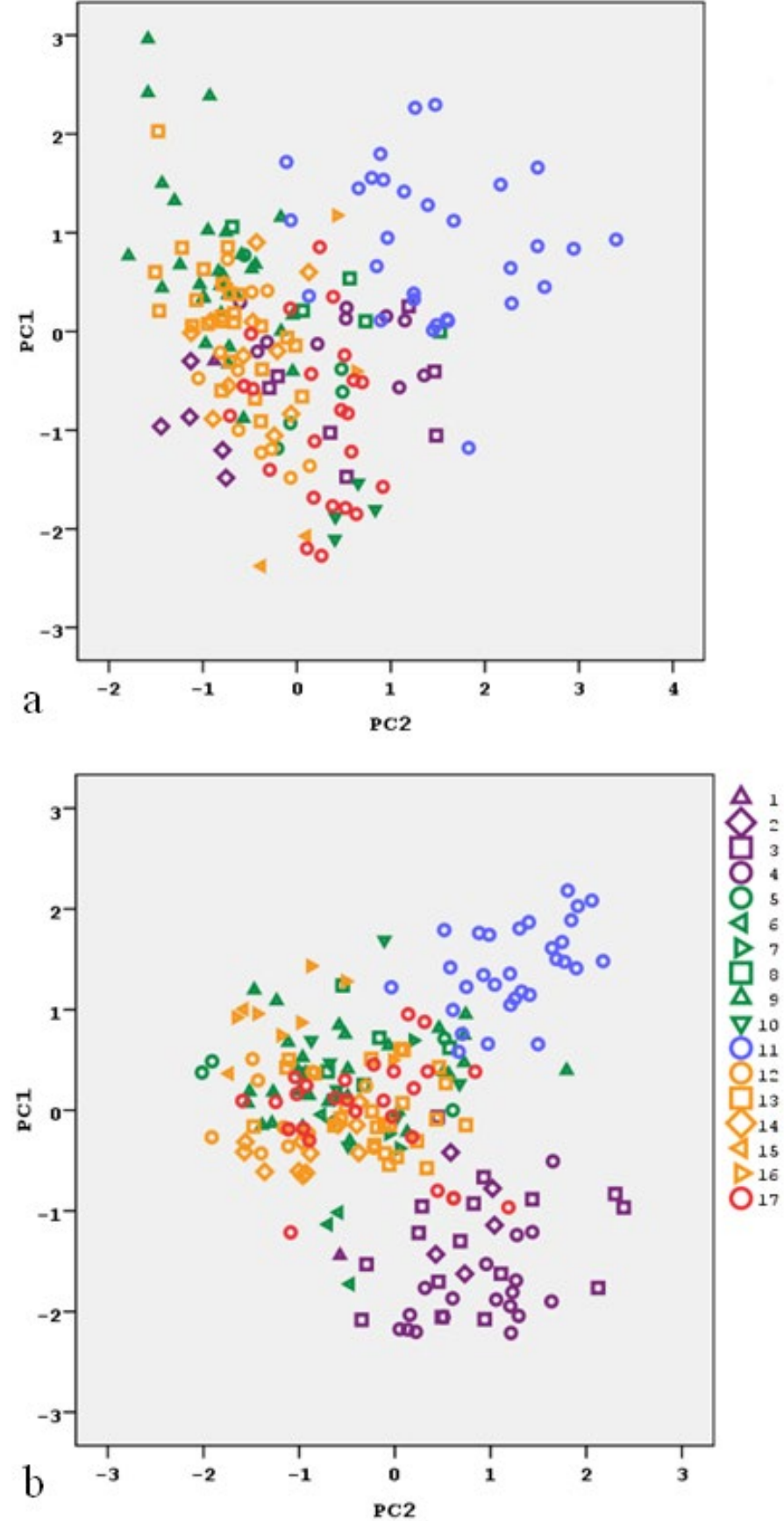

Fig.3. Distribution of 17 samples of sculpins of the genus Cyphocottus in the space of the first (PC1) and second (PC2) principal components: A. by numbers of neuromasts; B. by other meristic and plastic characters. Numeration of samples as in Table 1. Colour of symbols: violet $-C$. megalops; green and blue - a monochromic form of $C$. eurystomus (blue - the Selenga shallow water as the type locality); orange and red - a spotty form of $C$. eurystomus (red - the southern basin of Lake Baikal as the type locality).
Table 4. Component score coefficient matrix for analysis of morphological characters of 17 samples of the Cyphocottus sculpins

\begin{tabular}{|c|c|c|}
\hline \multirow[t]{4}{*}{ Characters } & \multicolumn{2}{|c|}{ Principal Component } \\
\hline & 1 & 2 \\
\hline & \multicolumn{2}{|c|}{$\%$ of variance } \\
\hline & 28.480 & 9.962 \\
\hline \multicolumn{3}{|c|}{ Meristic characters } \\
\hline $\begin{array}{l}\text { number of rays in the first dorsal } \\
\text { fin }\end{array}$ & -0.011 & 0.070 \\
\hline second dorsal fin & 0.012 & 0.169 \\
\hline left pectoral fin & 0.056 & -0.085 \\
\hline anal fin & 0.026 & 0.130 \\
\hline number of gill rakers & -0.027 & 0.009 \\
\hline \multicolumn{3}{|c|}{ Plastic characters in \% of standard length } \\
\hline head length & 0.032 & -0.230 \\
\hline length of the trunk & 0.015 & 0.192 \\
\hline height of the trunk & 0.088 & -0.053 \\
\hline height of caudal peduncle & 0.080 & 0.045 \\
\hline width of the trunk & 0.071 & -0.047 \\
\hline antedorsal distance & 0.046 & -0.196 \\
\hline postdorsal distance & -0.034 & 0.092 \\
\hline anteventral distance & 0.030 & -0.130 \\
\hline anteanal distance & 0.007 & -0.167 \\
\hline length of the caudal peduncle & -0.068 & 0.002 \\
\hline pectroventral distance & 0.063 & -0.008 \\
\hline ventroanal distance & -0.001 & -0.036 \\
\hline $\begin{array}{c}\text { length of insertions of the first } \\
\text { dorsal fin }\end{array}$ & 0.019 & -0.007 \\
\hline second dorsal fin & 0.043 & 0.034 \\
\hline height of the first dorsal fin & -0.002 & -0.058 \\
\hline second dorsal fin & 0.056 & 0.056 \\
\hline length of insertions of the anal fin & 0.056 & 0.093 \\
\hline height of anal fin & 0.048 & 0.093 \\
\hline length of pectoral fin & 0.062 & 0.089 \\
\hline length of ventral fin & 0.020 & 0.053 \\
\hline \multicolumn{3}{|c|}{ Plastic characters in $\%$ of head length } \\
\hline snout length & 0.067 & 0.026 \\
\hline longitudinal eye diameter & -0.079 & 0.050 \\
\hline postorbital distance & 0.071 & 0.051 \\
\hline width of the head & 0.075 & -0.043 \\
\hline head height near occiput & 0.087 & 0.000 \\
\hline head height near eye & 0.074 & 0.043 \\
\hline interorbital distance & 0.088 & 0.006 \\
\hline length of upper jaw & 0.076 & 0.041 \\
\hline length of lower jaw & 0.048 & 0.032 \\
\hline
\end{tabular}


8

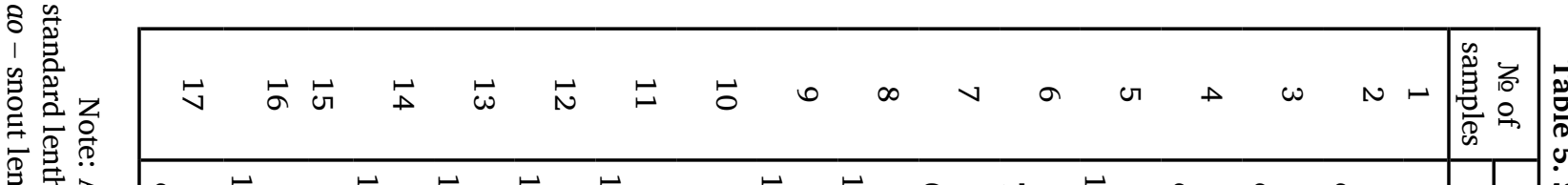

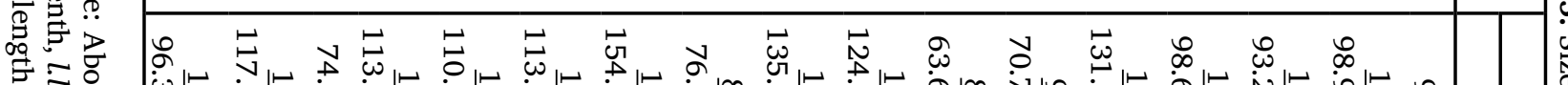

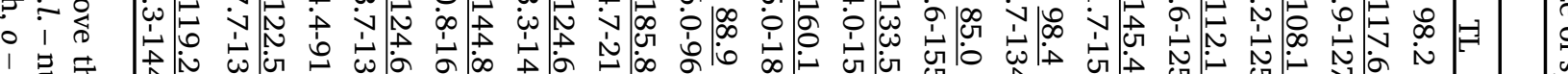

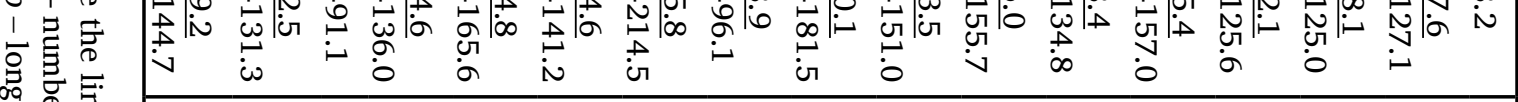

进

횽

통

용

可

只 孛

is

1

苋

ㄷ.

至:

도요.

茾

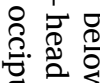

审

宛声官

I.

要

总. 家.

एँ

․ㅜ

$\infty \quad \infty \quad 0 \quad \%$ ம

审|屋

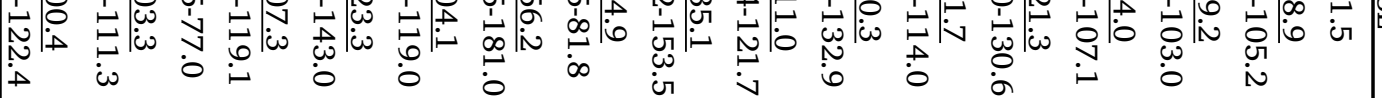

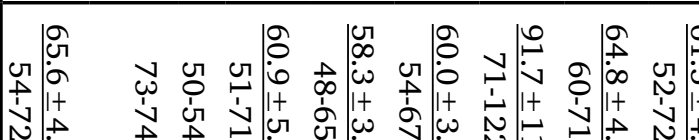

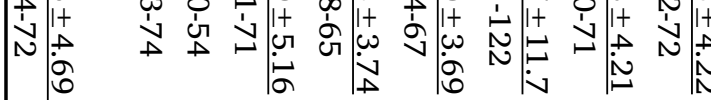

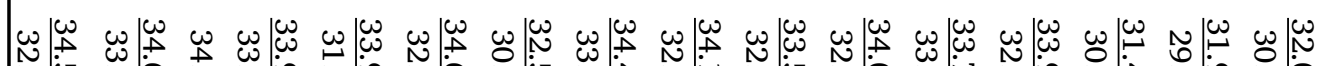

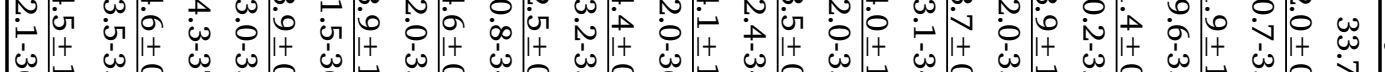

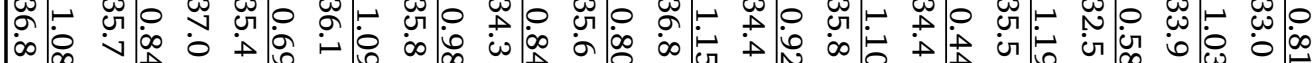

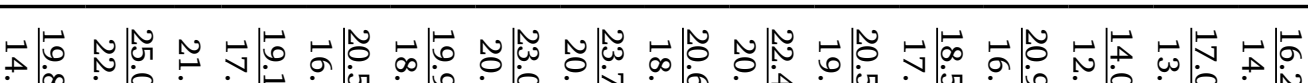

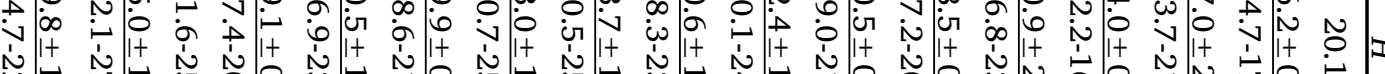

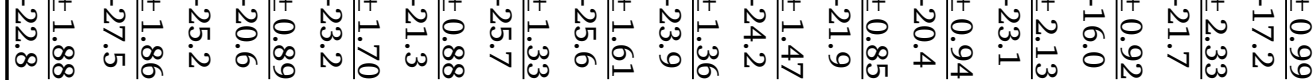

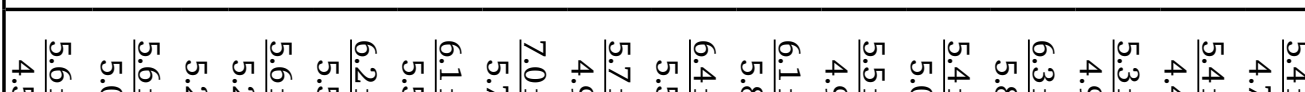

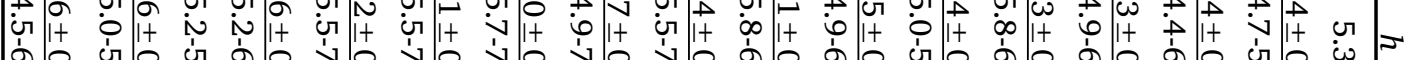

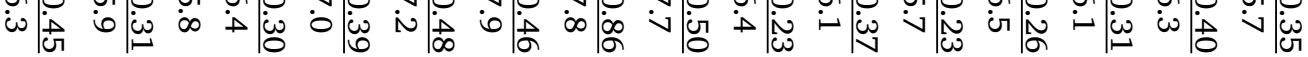

突官

㤩至

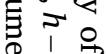

胥.

울

요용

串

क्षे

के

ज्ञे

急施

额

1

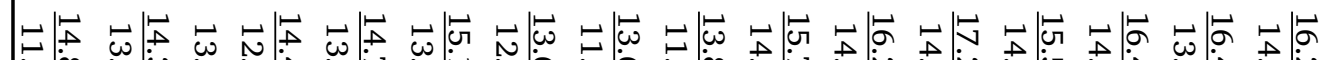

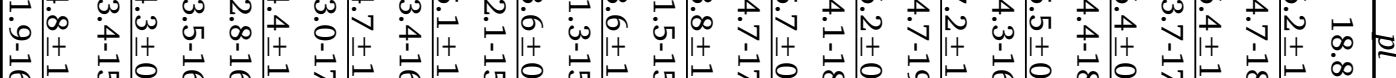

b|

బ

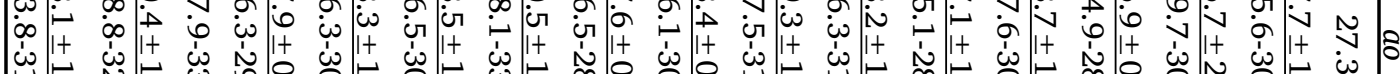

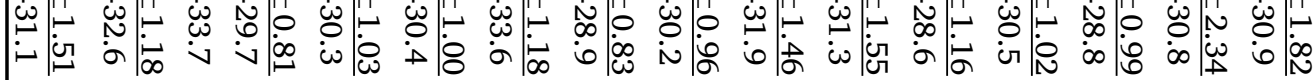

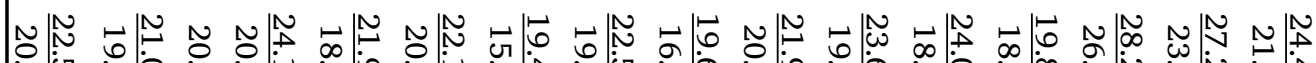

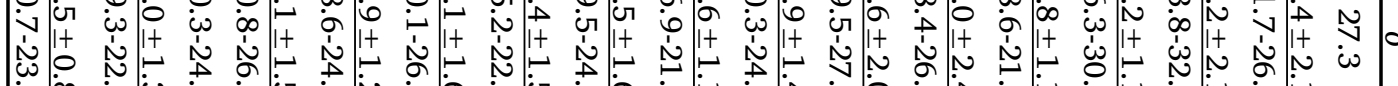

i)

स

品早

임

串节

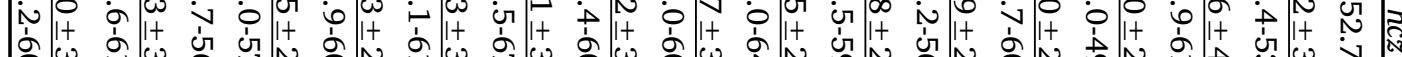

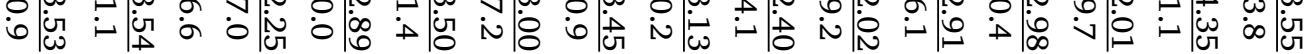

空

密

票学

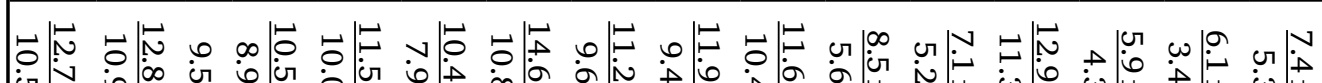

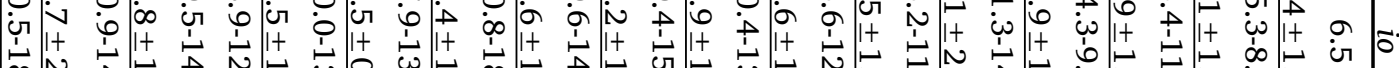

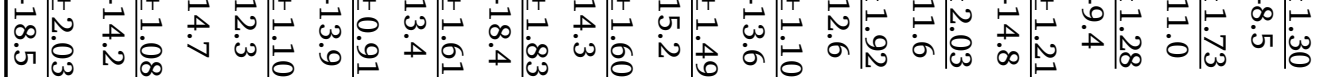


extreme forms of variability in sculpins of the genus Cyphocottus. The other selections, although filling the space between them, do not proceed to the intermediate form per se. They differ from each other by the number of neuromasts in sensory lines, colour and definitive sizes. Any combination of the selections, which is homogenous in one of these characters, will be heterogeneous in the rest. They all have the characters of $C$. eurystomus and differ from C. megalops. We have not found the intraspecific variability in C. megalops.

\section{Acknowledgements}

The study was carried out within the framework of LIN SB RAS State Task No. 0279-2021-0005.

The author thanks V.V. Pastukhov (Baikal Museum ICS SB RAS), professor I.B. Knizhin and professor V.V. Takhteev (Irkutsk State University), dr. S.V. Kirilchik, P.N. Anoshko, and I.V. Khanaev (Limnological Institute SB RAS) for assistance in organizing the fieldworks and collecting the material.

\section{Conflicts of interest}

The author declare no conflicts of interest.

\section{References}

Berg L.S. 1906. Übersicht der Cataphracti (Fam. Cottidae, Cottocomephoridae und Comephoridae) des Baikalsees. Zoologischer Anzeiger [Zoological Indicator] 30: 906-911. (in German)
Gratzianov V.I. 1902. Ichthyofauna of Lake Baikal. Dnevnik Zoologicheskogo Otdelenya Obshchestva Lyubiteley Estestvoznaniya, Antropologii i Etnografii [Diary of the Zoological Department of the Society of Lovers of Natural Science, Anthropology and Ethnography] 3(3): 18-61. (in Russian)

Gratzianov V.I. 1907. Opyt obzora ryb Rossiyskoy Imperii v sistematicheskom i geograficheskom otnoshenii [A synoptic essay of the fishes of the Russian Empire]. Trudy Otdela Ikhtiologii Imperatorskogo Russkogo Obshchestva Akklimatizatsii Zhivotnykh i Rasteniy [Proceedings of the Department of Ichthyology of the Imperial Russian Society for the Acclimatization of Animals and Plants] 4: 1-567. (in Russian)

Kontula T., Kirilchik S.V., Väinolä R. 2003. Endemic diversification of the monophyletic Cottoid fish species flock in Lake Baikal explored with MtDNA sequencing. Molecular Phylogenetics and Evolution 27: 143-155. DOI: 10.1016/ S1055-7903(02)00376-7

Laerd Statistics. 2015. Principal Components Analysis (PCA) using SPSS Statistics [Electronic resource]. Available at: https://statistics.laerd.com/spss-tutorials/principalcomponents-analysis-pca-using-spss-statistics.php (Last access date: 07.07.2021).

Sideleva V.G. 1982. Seysmosensornaya sistema i ekologiya baikal'skikh podkamenshchikovykh ryb [Sensory systems and ecology of the Baikal sculpins (Cottoidei)]. Novosibirsk: Nauka. (in Russian)

Sideleva V.G. 2003. The endemic fishes of Lake Baikal. Leiden: Backhuys Publishers.

Taliev D.N. 1948. K voprosu o prichinakh i tempakh divergentnoy evolyutsii baykal'skikh Cottoidei [The rate and the causes of divergent evolution in the Cottoidei from Lake Baikal]. Trudy Baykalskoy Limnologicheskoy Stantsii AN SSSR [Proceedings of the Baikal Limnological Station of the Academy of Sciences of the USSR] 12: 107-158. (in Russian)

Taliev D.N. 1955. Bychki-podkamenshchiki Baykala (Cottoidei) [Sculpins of Lake Baikal (Cottoidei)]. Moscow, Leningrad: Nauka. (in Russian) 